\title{
Kewajiban Dokter Dalam Memberikan Pelayanan Terhadap Pasien
}

\author{
Aarona Danylia \\ IIK Strada Indonesia \\ ronaliacute@gmail.com
}

\begin{abstract}
Abstrak
Dalam upaya menghindari atau mengurangi perselisihan medik, perlu dipahami konstruksi hubungan hukum antara dokter dan pasien. Dari hubungan hukum inilah yang akan menimbulkan perbuatan hukum dan menimbulkan akibat hukum. Dalam suatu akibat hukum, tidak dapat dipisahkan tentang siapa yang bertanggung jawab, sejauh mana tanggung jawab yang dapat diberikan. Ini menggambarkan bahwa hubungan dan dokter pasien jika dibangun, dapat dibagi berdasarkan dua faktor; transaksi terapeutik dan tindakan. Dalam hubungan terapeutik berbasis pasien - dokter, yang dikenal sebagai hubungan terapeutik atau terapeutik transaksi, ada ikatan antara pasien dan dokter dalam pengobatan penyakit atau pengobatannya. Perikatan yang terjadi bersifat inspanningsverbintennis dan bukan resultaatsverbintennis, dan harus sesuai dengan ketentuan Pasal 1320 KUHPerdata.
\end{abstract}

Kata Kunci:Dokter,Pasien Dan Hubungan Hukum

\section{Latar Belakang}

Hubungan antara dokter dengan pasien, telah terjadi sejak dahulu.Dokter dianggap sebagai seseorang yang memberikan pengobatan terhadap orang yang membutuhkannya. Hubungan hukum antara Dokter dengan pasien, berawal dari pola hubungan vertikal paternalistik layaknya bapak dan anak yang bertolak pada prinsip " Father knows best " dimana seorang dokter dianggap lebih mengetahui dan mampu untuk mengobati atas penyakit yang diderita oleh pasien. Kedudukan dokter lebih tinggi daripada kedudukan pasien dan dokter memiliki peranan penting di dalam perkembangannya. Pola hubungan antara dokter dan pasien yang demikian tersebut, lambat laun telah mengalami pergeseran kearah yang lebih demokratis yaitu hubungan horizontal kontraktual atau partisipasi bersama.1. Kedudukan dokter tidak lagi dianggap lebih tinggi daripada pasien, melainkan kedudukan dokter dan pasien dalam hubungannya tersebut sudah seimbang/sederajat. Pasien tidak lagi dianggap sebagai objek hukum tetapi pasien sudah sebagai subjek hukum. Segala sesuatunya dikomunikasikan diantara kedua belah pihak, sehingga menghasilkan keputusan yang saling menguntungkan diantara kedua belah pihak, baik dokter sebagai pemberi pelayanan kesehatan maupun si 
pasien sendiri selaku penerima pelayanan kesehatan.2. Hubungan antara dokter dan pasien, merupakan hubungan hukum yang didasarkan pada transaksi terapeutik. Dikatakan demikian, karena adanya kesanggupan dari dokter untuk mengupayakan kesehatan atau dokter berusaha semaksimal mungkin untuk melakukan penyembuhan si pasien dari penderitaan sakitnya. Penegasan mengenai hubungan ini sebagai suatu perjanjian (transaksi) dapat dilihat pada alinea pertama Kode Etik Kedokteran Indonesia (KODEKI). Oleh karenanya, hubungan hukum antara dokter dan pasien yang demikian lazim disebut sebagai perjanjian yang bersifat Inspaningverbintenis.

Dari hubungan hukum dalam transaksi terapeutik tersebut, timbulah hak dan kewajiban masing-masing pihak, pasien mempunyai hak dan kewajibannya, demikian juga sebaliknya dengan dokter. Umumnya perikatan yang timbul dari transaksi terapeutik termasuk golongan Inspanningsverbintenis yaitu perikatan yang prestasinya berupa upaya penyembuhan, bukan kesembuhan. Jadi kalau ternyata tidak sembuh setelah memperoleh pelayanan kesehatan, pasien tidak dapat menuntut ganti rugi kepada dokter. Pasien dapat menuntut ganti rugi kepada dokter jika ternyata dokter kur ang berupaya dalam pelayanan kesehatan atau tidak sesuai dengan standar profesi medik.

\section{Kasus/Masalah}

Upaya untuk mengetahui kewajiban seorang dokter dalam memberikan penanganan dokter ke pasien

Tanggung jawab dokter dalam Hukum

\section{Tinjauan pustaka}

Dasar hubungan Hukum Dokter Dengan pasien

Dasar Hukum Perlindungan terhadap Pasien

Tanggung jawab Hukum Akibat Tindakan Profesional

\section{Pembahasan}

Hubungan dokter dan pasien didasarkan hubungan kepercayaan. Pasien percaya terhadap dokter selau profesional dibidang kesehatan memiliki kemampuan, keterampilan, dan kesungguhan niat akan menolong dirinya sesuai dengan ilmu yang dikuasainya. Sebaliknya, dokter juga percaya bahwa pasien yang meminta bantuannya mempunyai kesungguhan niat untuk berupaya dan bekerjasama dengan dokter untuk mengatasi penyakit yang dideritanya. Oleh karena itu, hubungan antara dokter dan 
pasien tersebut merupakan hubungan yang sangat pribadi. Dengan kata lain,hubungan antara dokter dan pasien merupakan hubungan kerjasama untuk melakukan upaya kesehatan berdasarkan itikad baik dan kepercayaaan masing-masing pihak.

Pasal 52 Undang-Undang Nomor 29 Tahun 2004 Tentang Praktik Kedokteran, menjelaskan mengenai hak hak Pasien yaitu :

1) Mendapatkan penjelasan yang lengkap dari dokternya,

2) Meminta pendapat dokter lain,

3) Mendapatkan pelayanan sesuai kebutuhan medis,

4) Menolak tindakan medis,

5) Mendapatkan isi rekam medis.

Alinea Pertama Mukadimah Kote Etik Kedokteran Indonesia yang dilampirkan dalam surat Keputusan Mentri Kesehatan Nomor 434/MENKES/SK/X/1983 tanggal 28 Oktober 1983 tentang berlakunya Kode Etik Kedokteran Indonesia, ditegaskan bahwa sejak permulaan sejarah yang tersurat mengenai umat manusia sudah dikenal hubungan kepercayaan antara dua insan, yaitu san pengobat dan penderita. Dalam zaman modern hubungan itu disebut hubungan (transaksi) tarapeutik antara dokter dan pasien, yang berlakukan dalam suasana saling percaya mempercayai (konfidensial) serta senantiasa diliputi oleh segala emosi, harapan dan kekhawatiran makhluk insani.Dasar Hukum Perlindungan Terhadap Pasien. Berlakunya Undang-Undang Nomor 8 Tahun Tahun 1999 Tentang Perlindungan Konsumen (UUPK), maka hukum positif yang berlaku bagi Perlindungan konsumen adalah UUPK. Namun dalam Pasal 64 Tentang Aturan Peralihan, dinyatakan bahwa :"Segala ketentuan peraturan perundang-undangan yang bertujuan melindungi konsumen yang telah ada pada saat undang-undang ini diungkapkan secara khusus dan atau/ atau tidak bertentangan dengan ketentuan dalam undang-undang”. Perjelasan Pasal 64 tersebut dicamtumkan beberapa peraturan perundang-undangan yang dimaksud diantaranya Undang-Undang Nomor 36 Tahun 2009 Tentang Kesehatan. Dengan demikian maka dalam mengimplementrasikan Undang-Undang Perlindungan Konsumen sebagai perlindungan hukum bagi pasien selaku konsumen jasa pelayanan kesehatan, berlaku pula Undang-Undang Nomor 36 Tahun 2009 Tentang Kesehatan, Undang-Undang Nomor 29 Tahun 2004 Tentang Praktik Kedokteran dan berbagai peraturan perundang-undangan lainnya termasuk pula Keputusan Menteri Kesehatan R.I. Nomor: 434/MENKES/SK/X/1993 
Tentang Pengesahan Dan Pemberlakukan Kode Etik Kedokteran Indonesia Tanggung Jawab Hukum Akibat Kelalaian Tindakan Profesional.Tanggung Jawab Hukum Perdata didasarkan pada tiga Prinsip diantaranya a. Setiap tindakan yang menimbulkan kerugian atas diri orang lain yang beararti bahwa orang yang melakukan harus membayar kompensasi, sebagai wujud dari

pertanggung jawaban atas kerugian yang telah ditimbulkan.

b. Sesorang yang bertanggung jawab tidak hanya berupa tindakan dari kerugian yang telah diakibatkannya secara sengaja tetapi juga disebabkan karena kelalaian atau kesalahan dan kekurang hati-hatian yang dilakukan olehnya.

c. Sesorang harus memberikan pertanggung jawaban tidak hanya karena kerugian yang ditimbulkan dari tindakannya sendiri tapi juga karena kerugian yang ditimbulkan dari orang yang berada dibawah pengawasannya. Didasarkan ketentuan Buku III KUHPerdata Tentang Perikatan, tindakan medis yang dilakukan dokter adalah merupakan pelaksanaan kewajiban hukum dokter dalam menjalankan profesinya. Perikatan yang dibuat antara dokter dan pasien pada hakekatnya merupakan perikatan untuk melakukan sesuatu prestasi. Akan tetapi, tanggung jawab karena kesalahan dalam hukum perdata tidak hanya cukup ditentukan oleh ada tindaknya pelanggaran kewajiban hukum yang telah dilakukan dokter, tetapi juga adanya kerugian akibat dari pelanggaran yang terjadi. Untuk itu, perlu dibuktikan adanya hubungan kausal antara kesalahan dengan kerugian yang ditimbulkannya. Apabila tidak dapat dibuktikan adanya hubungan kausal tersebut, berarti tidak terjadi kesalahan atau kelalaian dalam tindakan medis. Akibat kelalaian dalam suatu tindakan harus dapat dipertanggung jawabkan secara hukum. Aspek pertanggung jawaban hukum dapat berupa hukum perdata, hukum pidana, dan hukum administrasi. Didasarkan prinsip pertanggung jawaban hukum perdata, setiap orang yang bersalah melakukan kelalaian sehingga menimbulkan kerugian pada orang lain, maka ia wajib mengganti kerugian. Kelalaian yang dilakukan dapat sesuatu sebagaimana dimaksudkan dalam Pasal 1234 HKUPerdata tentang subjek perikatan. Sehubungan dengan itu, J.H Leahy Taylor menyatakan, bahwa apabila tindakan melakukan dari seorang dokter oleh hakim dianggap suatu kelalaian, tidak peduli besar kecilnya tingkatan, apabila akibatnya serius makan ganti kerugiannya akanbesar. Akan tetapi, apabila kelalaian itu terbukti tidak menimbulkan kerugian, maka tidak akan diwajibkan untuk mengganti kerugian. 
Didasarkan Prinsip Pertanggung Jawaban Hukum Pidana, jika dalam pelaksanaan tindakan pengobatan, perawatan atau diagnosa terbukti adanya kesalahan, maka berarti pelaku melakukan kesalahan. Pertanggung jawaban hukum pidana sesuai

Pasal 360 Ayat (1) KHUP bahwa "Barang siapa karena kealpaannya menyeabakan seorang lain mendapat luka-luka berat, diancam dengan pidana penjara paling lama lima tahu atau kurungan paling lama satu tahun."

\section{Kesimpulan}

Kewajiban dokter dalam memberikan pelayanan kesehatan berupa promotif, kuratif, preventif dan rehabilitatif berdasarkan ukuran atau standar yang diwajibkan bagi profesi kedokteran. Kewajiban ini diatur dalam Pasal 51 huruf a UU Praktik Kedokteran berupa kewajiban mematuhi standar profesi dan standar operasional prosedur. Kewajiban dokter dalam standar profesi untuk melaksanakan profesi harus mempunyai kewenangan, kemampuan rata-rata, berbuat secara teliti, sesuai ukuran ilmu medis, situasi dan kondisi yang sama dan sarana upaya sebanding dengan tujuan konkrit tindakan. Kewajiban dokter terdapat dalam standar operasional prosedur berupa langkah-langkah baku yang dilakukan dokter. Selain itu, sebagai tenaga kesehatan dokter juga mempunyai kewajiban umum.

\section{Daftar Pustaka}

A.Mannas, Y. (2018). Hubungan Hukum Dokter Dan Pasien Serta Tanggung Jawab Dokter Dalam penyelenggaraan Pelayanan Kesehatan. Jurnal City Hukum, 7.

Alfiansyah. (2013). Tanggung Gugat Dokter atas Kesalahan Diagnosis pada pelayanan Medis. ejournal.uajy, 1-2.

Andriyani, S. Y. (2017). Hubungan Pola Asuh Orang Tua Dengan Perkembangan Anak. SNIJA 2017, 103. 